\title{
Theatrical Periodicals and the Ethics of Theatre in the Romantic Age
}

\author{
Nicoletta Caputo
}

In the Romantic Age, the number of the periodicals devoted exclusively to theatrical matters was huge, ${ }^{1}$ and for the richness and variety of their contents, and even for their prejudice and sectarianism, they prove extremely useful to the understanding of the complexity of the theatrical event in those years. In this essay, I will look at the strategies that such magazines adopted to arouse interest in the theatrical event and its protagonists, to influence public opinion, and to create an ideal audience and an "ideal theatre".

The materials that theatrical serials published were heterogeneous: reviews of performances, actors' biographies published in instalments - lines, letters, notes and circulars, anecdotes, gossip, and also courtroom records. The title-pages usually give a clear idea of the copiousness and variety of the contents of these magazines. See, for example: "The Roscius; consisting of original memoirs of the principal actors and actresses; strictures on the drama, and its interests; original essays, green-room gossips, Anecdotes, \&c \&c \&c". Or: The Drama; or, Theatrical Pocket Magazine:

\footnotetext{
${ }^{1}$ Between 1800 and 1830 some one hundred and sixty periodicals wholly concerned with drama and the theatre appeared throughout Great Britain. See Carl Joseph Stratman, Britain's Theatrical Periodicals, 1720-1967. A Bibliography, New York, New York Public Library, 1972, 8-16. On Romantic literary periodicals in general, see Walter Graham, English Literary Periodicals, New York, Octagon Books, 1966; John O. Hayden, The Romantic Reviewers 1802-1824, London, Routledge and Kegan Paul, 1969; and British Literary Magazines. The Romantic Age, 1789-1836, ed. Alvin Sullivan, Westport-London, Greenwood Press, 1983.
} 


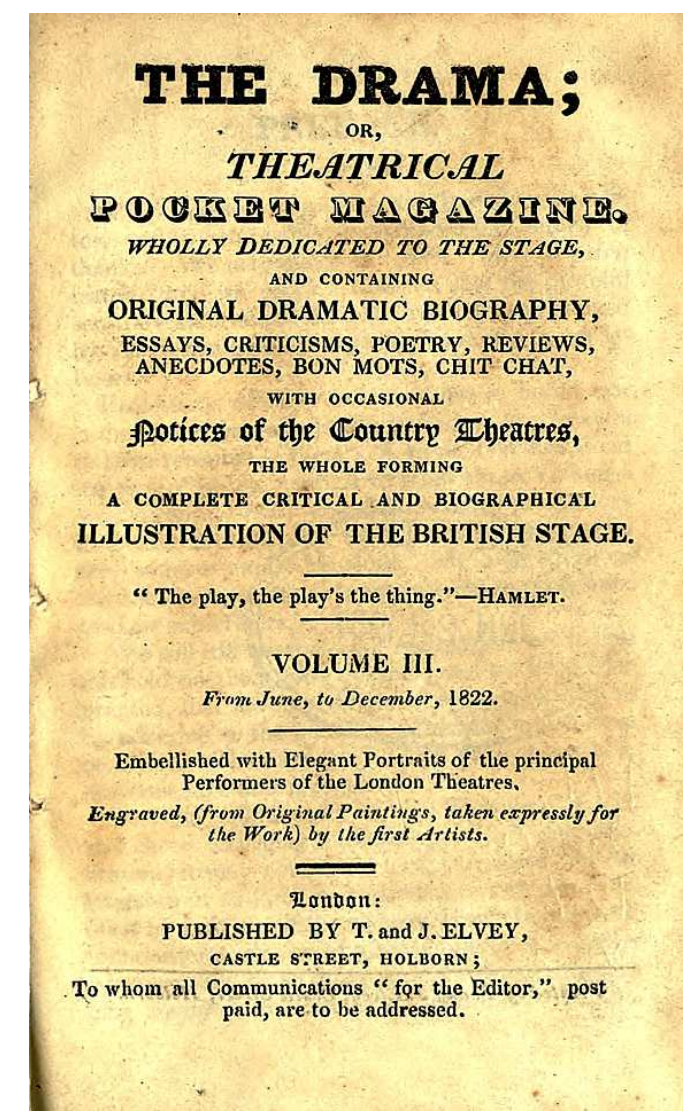

Title page of The Drama; or, Theatrical Pocket Magazine.

Theatrical magazines provided endless opportunities for discussion and debate that everybody could join: the editor and the critics; the readers, who usually wrote under pseudonyms and contributed with letters and lines inspired by theatrical events and characters; and the protagonists of the theatrical event itself - actors, authors and managers. Journals used to quote from each other and attack each other. ${ }^{2}$ Readers could not only use the magazine to state their opinions, but also to express their disagreement with the editor ${ }^{3}$ and to quarrel with other readers. ${ }^{4}$ Theatres used the press to communicate with the

\footnotetext{
${ }^{2}$ See The Theatrical Inquisitor, or Monthly Mirror XVI (April 1820), 228.

${ }^{3}$ See The Stage, I/21, (6 April 1820), 228; and The Theatrical Inquisitor, or Monthly Mirror XIV (February 1819), 108.

${ }^{4}$ See The Stage, II/15, II/17, II/18 and II/19.
} 
audience (often to justify their decisions and course of action) and with one another. The debates that were hosted by these periodicals were extremely heated and ingeniously constructed.

From February to April 1817, for example, The Theatrical Inquisitor followed very closely the querelle originating from Junius Brutus Booth's fluctuating conduct. These are, briefly, the facts. On $12^{\text {th }}$ February 1817 , Booth, who had already been applauded as a second Edmund Kean in Brighton, made his debut as Richard III at Covent Garden. His reception was enthusiastic, and all the critics commented on his astonishing resemblance to Kean. Booth, however, quarrelled with the theatre over money, and on his third announced performance as Richard he failed to turn up. On $20^{\text {th }}$ February he appeared at Drury Lane, as Iago to Kean's Othello, in what was to be the greatest histrionic battle of the century. As was obvious, Kean rose to the occasion and completely eclipsed his rival. On that night, Booth realized that he had fallen into a trap. He did not show up on $22^{\text {nd }}$ February, when Othello was announced for repetition, and he crawled back to Covent Garden with his tail between his legs. The dispute between the two Patent Houses, both claiming the right to Booth's services, was set down for hearing in the court of Chancery, but it was, eventually, settled privately in Covent Garden's favour.

The Theatrical Inquisitor investigated the controversy from a variety of points of view. The February issue contains a letter from a reader, a certain "Ignoto", who gives information about Booth's first theatrical experiences, and reveals confidential details about the player's negotiations with Covent Garden and Drury Lane. After this letter, the magazine presents a Drury Lane circular, following the actor's absence on the night in which he was announced to repeat the character of Iago. In the circular, two documents are enclosed: a note from Booth to the manager of Drury Lane, and an explanatory letter sent by the actor to the theatre Committee, with his reasons for returning to Covent Garden. The magazine also published a Covent Garden circular, written in reply to the Drury Lane one, in which the Covent Garden proprietors justify the actor's return to their theatre stating that it was in accordance with a pre-existing agreement. This circular too incorporates, in support of its assertions, a letter written by a member of the Sub-committee of Drury Lane. Lastly, the journal contains the reviews of the performances of Booth at Drury Lane as Iago, and at Covent Garden as Richard III.

The March issue is even richer in contributions on the subject. What the review intends to give is "a complete register of every 
document connected with the progress of Mr. Booth", and it wants its collection to be "at once uniform and final". 5 The survey opens with an account of Booth's performances at Covent Garden, amid the hostility of the audience. Its incipit also launches the Theatrical Inquisitor's campaign to boycott the actor:

We recur to the professional career of this gentleman with sentiments of equal disgust at the emptiness of his claims, and the cordiality of their reception. Some pleasant points, however, are afforded in a review of his progress, and, alluding to the clamour which attended his re-appearance on the boards of Covent Garden, we proceed with much satisfaction to record the most honourable ebullitions of censure and resentment. ${ }^{6}$

Notwithstanding its overtly hostile attitude towards the player, the journal, true to its professed commitment to thoroughness, also publishes contributions in his defence, like the note that Covent Garden posted near every avenue to the theatre on the day of Booth's debut, to justify his conduct and propitiate the audience. Booth's appeal to the public and Covent Garden's reply to Drury Lane's accusations are also included in the survey, but they are introduced by the following statement: "The documents annexed were successively promulgated, and experienced the neglect they deserved". 7

The newspaper's account of the controversy proceeds through notes and circulars in which the managers of the two Patent Theatres accuse and refute each other. However, what is interesting is not so much the querelle itself, but the attitude towards the unfortunate Booth, against whom a protracted, pitiless and composite assault is launched. In the April issue we even find a parodic attack on the actor in the form of a joking proclamation in which Booth is accused of having murdered Sir Giles Overreach and Richard Plantagenet, Duke of Gloucester. The sum of "Five Hundred thanks" is promised as a reward "to be paid by the Commissioners of the Editor's Treasury, upon the said Junius Booth being apprehended and lodged in any one of the Monthly Magazines". ${ }^{8}$ In that same issue, we find a review of the Memoirs of Junius Brutus Booth, in which the antipathy towards the actor is, again, vented, the biographer's assertions are refuted and

\footnotetext{
${ }^{5}$ The Theatrical Inquisitor, or Monthly Mirror, X (April 1817), 274.

${ }^{6}$ The Theatrical Inquisitor, and Monthly Mirror, X (March 1817), 189.

${ }^{7}$ Ibid, 193.

${ }^{8}$ Ibid., X (April 1817), 279.
} 
the work is labelled as "a barefaced attempt [...] to impress the imbecile, the wavering and the credulous". ${ }^{9}$ The Theatrical Inquisitor is utterly determined "to extinguish Mr Booth, and the cupidity which exalts him", ${ }^{10}$ and its critics are so outspoken in their judgments that, in a letter to the editor, a reader accuses the journal of being "disgraced by interested and malignant attacks on Mr Booth; from writers, whose effrontery, ignorance, and falsehood, render them despicable even to pity" 11

Even after the controversy has subsided, the magazine continues to boycott the actor. In the July issue, for example, while reviewing a performance of Othello in which Booth plays Iago, the critic only mentions him at the very conclusion of his report, and just to express his wish to see Mr Young's return to Iago, because in that way:

... the miserable efforts of Mr Junius Booth, which were repeatedly hissed, would be excluded, and in that enjoyment we should trace unceasing motives for congratulation and delight. This wretched creature lies on the excellence of Shakespeare, like an incubus on the bosom of a Circassian beauty. ${ }^{12}$

But, again, the overt hostility to Booth is, sometimes, overcome by the journal's efforts at thoroughness, and in the issue of November 1818, Booth's self-exculpation from the accusation of plagiarism is reprinted from The Edinburgh Reflector. ${ }^{13}$ In September 1820, in accordance with the periodical's alleged claims to impartiality, we even find a review in which Booth's superiority to Kean in King Richard III's tent scene is stated. On that occasion, however, we also find a footnote in which the editor dissociates himself from the correspondent's opinion. ${ }^{14}$

Parallel to Booth's boycott, ${ }^{15}$ is a campaign in favour of Edmund Kean, for whom the Theatrical Inquisitor, like the press in general,

\footnotetext{
${ }^{9}$ Ibid., X (April 1817), 281-86.

${ }^{10}$ Ibid., X, (March 1817), 228.

${ }^{11}$ Ibid., X, (May 1817), 338.

${ }^{12}$ Ibid., XI, (July 1817), 70.

${ }^{13}$ Ibid., XIII, (November 1818), 399-400.

${ }^{14}$ Ibid., I (September 1820), 198-201.

${ }^{15}$ Even as late as August 1820, Booth was still experiencing the critic's harshness and contemptuous irony: "That admirable actor, Mr. Booth, has been engaged to perform in conjunction with his old antagonist, Mr Kean, to whose superior fortune, after frequent defiance, he has wisely submitted. This incomparable genius was announced by his fine old Roman names of Junius Brutus, but even that novelty has not tempted us to honour him with our notice; and so there he stands, respected purchaser, to court
} 
shows an admiration that borders on hagiography ${ }^{16}$. Despite its claims to offer "genuine and unbiassed [sic] opinions", ${ }^{17}$ the magazine always takes sides. It greatly contributes to Kean's self-fashioning by publishing many of his letters and notes. The reviews of his performances are invariably favourable, and it publishes lines in his honour ${ }^{18}$ and readers' contributions that highly praise his merits. See, for example, the following opinions, which are expressed in two letters to the Editor:

Like the immortal Bard whose works he has so finely illustrated, $\mathrm{Mr}$ Kean, by the power of his genius, has created a new paradise in the world of taste and imagination. ${ }^{19}$

The Sir Giles Overreach of Kean is one of those masterpieces of excellence, which almost persuade us that human nature may be perfect. $^{20}$

The journal even conducts an enquiry to dissipate the rumours that the Wolves, of which Kean was President, was a club created for the purpose of opposing any new performers who might rival the actor. ${ }^{21}$ The newspaper does not seem to perceive the calculation behind Kean's calling Booth to play Iago to his Othellore, and it also

thy applause, unvisited by our criticism, and unhurt by our censure." The Theatrical Inquisitor, and Monthly Mirror, I (August 1820), 148.

${ }^{16}$ In October 1817, The Theatrical Inquisitor related that the actor, on his way to Liverpool, had performed one night at the Buxton Theatre, where he was to be remunerated with half the receipts of the evening. However, having known that the manager had a large family, the player refused to take his share (The Theatrical Inquisitor, XI (November 1817), 277). The Drama; or, Theatrical Pocket Magazine was another journal that was always ready to bear witness to Kean's "goodness of heart". In June 1822, for example, it reported that the actor devolved the whole proceeds of a benefit evening to the Irish peasantry, and it thus commented on the deed: "It was a noble sacrifice, and will forever immortalize his name" (The Drama; or, Theatrical Pocket Magazine, III/1 (June 1822), 36). Three months later, the magazine congratulated on finding a tribute to Kean's generosity in an American paper (The Drama; or, Theatrical Pocket Magazine, III/4 (September 1822), 208).

${ }^{17}$ The Theatrical Inquisitor, and Monthly Mirror, XIV (March 1819), 294.

18 "To Mr. Kean", Theatrical Inquisitor, and Monthly Mirror, XIII (Dec. 1818).

${ }^{19}$ The Theatrical Inquisitor, and Monthly Mirror, VIII (January 1816), 20.

${ }^{20} \mathrm{Ibid}$., VIII (February 1816), 127.

${ }^{21}$ Ibid., VIII (May 1816), 393-4.

${ }^{22}$ These are the lines the review publishes 'On his recommendation of Mr Booth to the Drury-lane Committee': "Disinterested Kean, whose lofty soul, / Stranger alike to envy's mean controul, / Or the black chains of prejudice, which bind / In slavish bondage thousands of mankind; / Thou, by an act of unexampled zeal, / In friendship's 
strenuously supports the actor in the controversy with Mr Bucke, the author of The Italians. This was another famous querelle that The Theatrical Inquisitor investigated in a plurality of ways, publishing: a letter to the Editor on the subject, Mr. Bucke's letter to Kean and the actor's reply, and a review of six pamphlets originated from the controversy, which includes an account of the evening in which the tragedy was performed.

But, if up to April 1819 Kean emerges from the pages of the magazine as a hero, only a few months later the attitude of the journal towards the actor suddenly changes. The reason for such a radical shift is Kean's announced departure for America, a decision that The Theatrical Inquisitor and other periodicals interpret as truly treason: according to The Inquisitor, the actor has chosen to "desert the banner that has led him to reputation". After expressing its dissatisfaction with Kean's resolution, the magazine embarks on a campaign of denigration against him. Now his writings are dismissed as "a curiosity of no common description. [...] precious piece[s] of arrogance, hypocrisy, and conceit, [...] unworthy of much consideration". ${ }^{23}$ The reviews of his performances, far from being enthusiastic, stress the inadequacies of his acting, and it is declared that: "by unconquerable deficiencies [...] in the great requisite of voice, and the still greater attribute of judgment, his rights are irretrievably forfeited to classical applause, and superior distinction". ${ }^{24}$ In August 1820, when the player is finally about to leave the country, the journal explicitly threatens to take revenge on the actor as soon as he comes back to England:

On the subject of Mr. Kean's departure some very judicious remarks will be found in another part of our miscellany; but we cannot help observing that this flight from the friends who have raised him to estimation and emolument, is a most ungracious step, and on his return, would warrant the exercise of that neglect and indifference he has certainly shown towards his public supporters. ${ }^{25}$

Disappointed by Kean's behaviour, The Theatrical Inquisitor has turned its back on him, and, in its "free exercise of impartial opinion", it now extols William Charles Macready.

cause, which few but thee could feel, / Hast nobly rais'd a rival to thy fame, / But, by the deed, immortaliz'd thy name" (The Theatrical Inquisitor, and Monthly Mirror, X (March 1817), 216).

${ }^{23}$ The Theatrical Inquisitor, and Monthly Mirror, XV (October 1819), 186, 188.

${ }^{24}$ Ibid., XV (1819), Supplement, 363.

${ }^{25}$ Ibid., I (August 1820), 149. 
So far, I have considered only The Theatrical Inquisitor, but the strategies the various periodicals adopted were much the same. Their attitude with regard to an individual actor or a particular event could change, but they all moved freely between the extremes of praise and censure, with no fear of running into manifest contradiction. That was because they all shared a performative intent, insofar as they did not limit themselves to relate events, describe performances and express aesthetic judgments; they aimed, instead, at creating an ideal theatre, peopled by ideal actors and ideal spectators. For that reason, when an actor or any other theatrical protagonist failed to live up to expectations, they deserted him, or, even worse, they boycotted him. In that, they were not dissimilar from audiences, quick to abandon their favourites, whenever their behaviour was found morally reprehensible. Kean's career, with its ups and downs in popularity, offers many such instances. Theatre-goers were extremely touchy and revengeful: they were easily enthralled by a performer's artistry, but when that same actor disappointed them, they were loath to grant forgiveness. The press, on its part, greatly contributed both to create myths and to set crowds up against the poor players as soon as they incurred its disapproval or displeasure.

Theatrical periodicals were concerned with the ethics of theatre. Their contributors, when stating their opinions and commenting upon theatrical events and characters, were incessantly dealing with concepts of right and wrong behaviour, and dictated rules of conduct directed to the actors and to the audience. The Dramatic Censor, for example, reprehended Charles Kemble for his habit of looking at the audience, instead of watching his fellow-performers while playing:

Mr C. Kemble must pardon us, if we take the liberty of reminding him of a certain bad habit he has (in common with but too many of his brother - and, we might add - sister-performers), of taking a survey of the audience, and more especially of his fair friends in the boxes; instead of watching, as propriety requires, the effect of his speech on the party to whom his words are addressed. This custom owes its rise entirely to vanity, and that inordinate thirst for admiration, which characterises a weak mind. ${ }^{26}$

True to its name, in September 1801 The Dramatic and Literary Censor conducted an enquiry to verify with whom the blame for George Frederick Cooke's absence on the opening night of Covent

\footnotetext{
${ }^{26}$ The Dramatic Censor; or Weekly Theatrical Report, III (18 January 1800), 73.
} 
Garden rested. Having ascertained that the blame attached to the actor and not the manager, the magazine bitterly rebukes Cooke, and then proceeds to reprove the manager as well, for having attempted to substitute the play without a previous apology. Such an act is defined as "highly reprehensible, indecent and flagitious" and the public is praised for its ensuing "manifestations of honest resentment", and for having "treated with contempt [...] insulted, spurned at, and rejected" the manager's tardy apology. However, the manager is, again, acquitted for his subsequent behaviour towards the audience, which other serials have described as pert and contemptuous. ${ }^{27}$ The discussion over the reasons for Cooke's absence from London continues in two October issues. There, the actor is literally put on trial for his conduct, and the versions of Cooke's apology that other theatrical periodicals had published are given as proofs in the proceeding. All that is aimed:

[...] in the first place, to clear the innocent from imputation, and refer the blame to its proper object - and, secondly, to call Performers to a just sense of duty - to impress upon their minds this salutary maxim, that the higher they rank in public estimation - the more they are patronised and rewarded by a liberal public - the greater ought to be their solicitude to please - the greater their dread of giving cause of offence, and forfeiting the support and encouragement they receive. ${ }^{28}$

If actors are the favourite targets of the periodicals' displeasure - and Kean is a perfect example of that ${ }^{29}$ - the actions of theatre managers are also called into question. In the famous controversy between the Patent Theatres and the Minor Theatres - a dispute that was occasioned by the melo-dramatising and performing of Richard the Third at the Coburg and ended up in the courtroom with the Proprietor of the Royal Coburg Theatre prosecuted for infringing his licence The Theatrical Inquisitor, in its strenuous opposition to the monopoly of dramatic amusement, launched a campaign against Mr. Elliston, the

\footnotetext{
${ }^{27}$ See The Dramatic and Literary Censor, V (September 1801), 81-84.

${ }^{28}$ The Dramatic and Literary Censor, V (October 30, 1801), 155.

${ }^{29}$ The Roscius, for instance, extensively discussed the subject of "the public v. Kean" and the actor's fall in popularity after the trial in which Kean was involved for his adulterous relationship with Charlotte Cox, in January 1825. See The Roscius, I/3 (February 1, 1825), 55-59, 65-67; and The Roscius, I/4 (February 15, 1825), 87-89. The lawsuit had an enormous resonance in the papers, which even published transcripts of the courtroom records. See The Drama; or, Theatrical Pocket Magazine, VII/4 (January 1825), 213-19.
} 
Lessee of Drury Lane, who is accused of parricide (and, in passing, of being a drunkard). ${ }^{30}$

On other occasions, it is the unruly behaviour of the public that is severely reproved. The Theatrical Inquisitor, for example, repeatedly accuses the audience of illiberality and of exhibiting a "spirit of unfeeling and undistinguishing hostility towards the débutant". ${ }^{31}$ In the report of the debut of a certain Mr. Meggett, the spectators are defined Yahoos, and the critic asserts that he has "no terms sufficiently strong to express [his] indignation at the brutal and unfeeling conduct of the major part of the audience". ${ }^{32}$ Sometimes, however, those rebuked in the theatrical press are the contributors themselves. It is, again a reader of The Theatrical Inquisitor who accuses the critics of being prejudiced against new productions:

I am of opinion that our critics of the present day, are not only ill natured and fastidious, but that they judge of all dramatic productions by some standard of ideal excellence, which has found no parallel in actual existence: indeed, they are perpetually raving on a set of terms which, to me, and I almost apprehend to themselves, are without any precise signification; to wit, legitimate drama, classical drama, genuine drama, and likewise some of reprobation; as German horrors, Melo-drame, \&c.

It is their custom to condemn every production of our present day, either for its departure from the first, or its adoption of the other class of peculiarities. ${ }^{33}$

Thus far, I have been concerned with the theatrical periodicals' aims and intentions, and I have tried to demonstrate that the press strongly felt it had a civilizing mission, and relentlessly endeavoured to refine the taste of the audience and, even more, to create an ideal theatre, peopled by ideal actors and ideal spectators. However the author of the last quotation, raises a doubt regarding the theatrical critics' credentials. In fact, despite their pretensions and sententiousness, the contributors to these journals do not always appear qualified to accomplish their task. The Prompter, for example, is one of the first English periodicals devoted wholly to drama and the theatre. In the declaration of intents that opens the first issue, it is boldly stated that the object of the publication is "the perfection of the drama", and that

\footnotetext{
${ }^{30}$ See The Theatrical Inquisitor, and Monthly Mirror January-August 1820.

${ }^{31}$ The Theatrical Inquisitor, and Monthly Mirror, VII (September 1815), 229.

${ }^{32}$ Ibid., VII (August 1815), 149-51.

${ }^{33}$ Ibid., XIV (May 1819), 351.
} 
its contributors "are not altogether unqualified for the undertaking". ${ }^{34}$ But three weeks later, the review of a performance of Richard the Third with John Philip Kemble as Richard shows the inconsistency of such claims. The critic opens his report presenting the play:

This play was entitled the Life and Death of this prince; but the Tragedy comprizes, at most, but the last eight years of his time: for it opens with George Duke of Clarence being shut up in the Tower, which happened in the beginning of the year 1477, and closes with the death of Richard at Bosworth field, which battle was fought on the $22^{\text {nd }}$ August, in the year 1485. Several dramas on the present subject had been written before Shakespeare attempted it. ${ }^{35}$

These words are taken verbatim from Theobald's and Steevens's editions of The Plays of William Shakespeare. Unfortunately, the play the critic has witnessed at Drury Lane is not Shakespeare's, but Cibber's; and in Cibber's adaptation the Duke of Clarence does not appear at all, and the play opens, instead, with the murder of King Henry the Sixth, which took place in 1471. The critic's doubtful competence irremediably casts a shadow over the trustworthiness of the accounts contained in the theatrical periodicals and makes the job of the theatre historian hard, and even dismaying and frustrating ${ }^{36}$.

A curious note that appeared in The Drama; or, Theatrical Pocket Magazine in June 1824 gives us an idea of how arduous the task of the theatre historian is and how difficult for him to find his way among the multitude of different and even contrasting opinions of contemporary reviewers, when trying to understand or analyse the acting style of a particular actor or actress of the past and evaluate his or her performances. In a note on the first appearance of a certain Kent as Richard of Gloucester, The Drama, instead of providing an assessment of the merits and demerits of his interpretation, reports various extracts (seventeen in total) from the newspaper accounts. As the critic ironically notes in introducing the survey, the quoted comments "differ most strangely":

"His voice is decidedly bad." - (Morning Post)

"His voice is powerful and varied." - (Morning Chronicle)

\footnotetext{
${ }^{34}$ The Prompter, I (October 24, 1789), 6.

${ }^{35}$ The Prompter, XI (November 13, 1789), 65.

${ }^{36}$ On the difficulties and frustrations experienced by the theatre historian, see Cary M. Mazer. "Shakespeare, the Reviewer, and the Theatre Historian", Shakespeare Quarterly, XXXVI/5 (1985), 648-69.
} 
"His voice is thin, peculiar, puerile, and unpleasant." - (New Times)

"The fact is, Mr. Kent has more power of voice than Mr. Kean, and he plays Richard full of fire and impatient ambition." (Theatrical Observer)

"Mr. Kent is of low and slight stature, with strong lungs, and yet stronger nerves." - (Morning Herald)

"His deportment altogether without a touch of self-possession." (Times)

"He evinced so much self-possession that we must assume he has either a high estimate of his own powers, or has been accustomed to the stage." - (Morning Advertiser)

"His action, though redundant, is marked by the ease which experience and self-possession can communicate." - (Morning Chronicle)

"The tent-scene was desperately extravagant." - (Morning Advertiser)

"The best hit was the tent-scene." - (Times)

"His chief defects are from want of anything but genius. - We are sure he can correct them." - (Theatrical Observer)

"We cannot remember a solitary instance in which he evinced genius, or superior talent." - $(\text { New Times })^{37}$

Today, we know about the performances of Kemble, Cooke, Kean, Booth, Macready and their fellow-actors mainly thanks to the descriptions writers like William Hazlitt, Leigh Hunt and Charles Lamb gave in the reviews and magazines of the period. However, as I have tried to show in this essay, dramatic criticism was not the exclusive property of such famous thinkers and intellectuals, whose contributions to the field have been variously extracted from their original context and anthologised. Even if contributors to theatrical journals were often less gifted than the critics I have just mentioned, and, perhaps, not always produced dramatic criticism of lasting value, specialized periodicals of drama cannot simply be dismissed as curiosities, insofar as they invariably offer precious information and insights into stage matters: performers and productions, but also the theatrical phenomenon in its various aspects and, last but not least, its reception.

Eyewitness accounts of performances appear uneven in quality, and, certainly, not all the critics had the sensibility, the subtlety, the education and the talent of William Hazlitt and the other famous Romantic intellectuals who, more or less regularly, contributed to

${ }^{37}$ The Drama; or, Theatrical Pocket Magazine, VI/4 (June 1824), 190-91. 
literary periodicals with reviews or original creations ${ }^{38}$. Nonetheless, the distinction between "high" criticism and "low" criticism cannot be pushed too far, and that for a number of reasons. First of all because, as has already been noticed, there is more to theatre than the critical assessment of actors and productions; theatrical news matter, anecdotes and gossip of managers and stage folk are equally useful to the theatre historian, and valuable materials can be found in any kind of journal. On the other hand, even the most serious literary periodicals included anecdotic, ephemeral or frivolous matters. In addition, critics of high repute could be just as biased and partisan as the reviewers I have been concerned with in this essay. Critical inconsistency was a feature of Romantic literary serials in general. In fact, with some notable exceptions, reviewers wildly vacillated in their criticisms, and authors, like actors, were damned and praised and damned again in successive numbers by the same critics.

In his Theatre in the Age of Kean, Joseph Donohue asserts that "then as now, a large proportion of theatrical journalism was at the least undistinguished, and some was heavily biased (gratuitously, or for a price), supercilious, condescending, reactionary or just grossly ignorant" ${ }^{\prime 39}$. This is undeniably true. The bias and partisanship of theatrical periodicals, together with the critics' doubtful reliability, obviously compel the theatre historian to use extreme caution in his judgments, but, at the same time, render his task invariably intriguing and captivating.

\footnotetext{
${ }^{38}$ Besides Hazlitt, Hunt and Lamb, we find, just to name a few: Thomas Robert Malthus, Sir Walter Scott, S.T. Coleridge, James Hogg, Percy B. Shelley, John Keats, William Godwin, Robert Southey and Thomas De Quincey.

39 Joseph Donohue, Theatre in the Age of Kean, Totowa, New Jersey, Rowman and Littlefield, 1975, 145.
} 